\title{
Hydroxy-bridged Active Site States of [NiFe]-Hydrogenase Unraveled by Cryogenic Vibrational Spectroscopy and DFT Computations
}

Giorgio Caserta, ${ }^{\mathrm{a}_{\ddagger}}{ }^{*}$ Vladimir Pelmenschikov, ${ }^{{ }^{a}}{ }_{\ddagger}$ Christian Lorent, ${ }^{\mathrm{a}}$ Armel F.Tadjoung Waffo, ${ }^{\mathrm{a}}$ Sagie Katz, ${ }^{\mathrm{a}}$ Lars Lauterbach, ${ }^{\mathrm{a}}$ Janna Schoknecht, ${ }^{\mathrm{a}}$ Hongxin Wang, ${ }^{\mathrm{b}}$ Yoshitaka Yoda, ${ }^{\mathrm{c}}$ Kenji Tamasaku, ${ }^{\mathrm{c}}$ Martin Kaupp, ${ }^{\mathrm{a}}$ Peter Hildebrandt, ${ }^{\mathrm{a}}$ Oliver Lenz, ${ }^{\mathrm{a}}$ Stephen P. Cramer, ${ }^{{ }^{*}}$ and Ingo Zebger $^{a^{*}}$

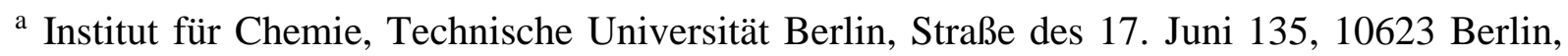
Germany.

b SETI Institute, 189 Bernardo Avenue, Mountain View, CA 94043, United States.

c Japan Synchrotron Radiation Research Institute, SPring-8, Hyogo 679-5198, Japan.

*corresponding authors

‡ These authors contributed equally

\begin{abstract}
The catalytic mechanism of $\mathrm{H}_{2}$ conversion by [NiFe]-hydrogenase is subject of extensive research. Apart from at least four reaction intermediates of $\mathrm{H}_{2} / \mathrm{H}^{+}$cycling, there is also a number of resting states, which are formed under oxidizing conditions. While not directly involved in the catalytic cycle, knowledge of their molecular structure and reactivity is important, because these states usually accumulate in the course of hydrogenase purification, and they may also play a role in vivo during hydrogenase maturation. Here, we applied low-temperature infrared (cryo-IR) and nuclear resonance vibrational spectroscopy (NRVS) to the isolated catalytic subunit, HoxC, of the heterodimeric regulatory [NiFe]-hydrogenase $(\mathrm{RH})$ from Ralstonia eutropha. Cryo-IR spectroscopy revealed that the HoxC protein can be enriched in almost pure redox states suitable for NRVS investigation. NRVS analysis of the hydrogenase catalytic center is usually hampered by strong spectral contributions of the FeS clusters of the small, electron-transferring subunit. Therefore, our approach to investigate the FeS cluster-free, ${ }^{57} \mathrm{Fe}-$ labeled HoxC granted an unprecedented view onto the active site modes, including those obscured by FeS cluster-derived bands. Rationalized by density functional theory (DFT) calculations, our data allow the structural description two hydroxy-containing resting states. Our work highlights the relevance of cryogenic vibrational spectroscopy and DFT to elucidate the structure of barely defined redox states of the [NiFe]-hydrogenase active site.
\end{abstract}




\section{Introduction}

Hydrogenases catalyze the reversible cleavage of dihydrogen, thereby making use of earth-abundant transition metals. Among them, $\mathrm{O}_{2}$-tolerant $[\mathrm{NiFe}]$-hydrogenases are particularly attractive in view of a remarkable catalytic performance under usually inhibiting oxic conditions. ${ }^{1,2}$ Buried deeply in the large subunit of the heterodimeric functional unit, the [NiFe] active site contains a $\mathrm{Ni}$ and an Fe ion bridged by two cysteine (Cys) residues; two additional terminal Cys bind exclusively to the $\mathrm{Ni}$, while two $\mathrm{CN}^{-}$and one $\mathrm{CO}$ ligands participate in the coordination of the $\mathrm{Fe}$ (Fig. 1). $\mathrm{H}_{2}$ splitting releases two protons that are transferred to nearby proteinaceous $\mathrm{H}^{+}$acceptors. The concomitantly released electrons are channeled through a FeS cluster chain located in the small subunit to the hydrogenase's redox partner. $^{3-5}$ Although $[\mathrm{NiFe}]-$ hydrogenases have been the subject of intensive research for decades, many questions remained open regarding the nature of some resting states as well as catalytically relevant intermediates. Infrared (IR) spectroscopy represents a valuable technique to monitor the redox-sensitive $\mathrm{CO}$ and $\mathrm{CN}^{-}$ligands of the active site, and electron paramagnetic resonance (EPR) spectroscopy provides important electronic and structural information on the active site redox states. ${ }^{6-8}$ During catalysis, nickel serves as redox-active metal center, while iron retains an $\mathrm{Fe}^{\mathrm{II}}$ low-spin configuration throughout the entire catalytic cycle (Fig. 1, left panel). ${ }^{1,9}$ However, some redox states are EPR-silent, and direct IR spectroscopic detection of possible hydride $\mathrm{H}^{-}$and hydroxy $\mathrm{OH}^{-}$bridging ligands at the active site is hindered by strong spectral contributions of the protein and/or the solvent. Furthermore, Resonance Raman (RR) spectroscopy has also been applied for the analysis of metal-ligand vibrations of [NiFe]hydrogenase intermediate states characterized by a vacant bridging position between $\mathrm{Ni}$ and $\mathrm{Fe}$ (i.e. $\mathrm{Ni}_{\mathrm{a}}-\mathrm{S}$ and $\mathrm{Ni}_{\mathrm{a}}-\mathrm{L}$, Fig. 1). ${ }^{10,11}$

Nuclear resonance vibrational spectroscopy (NRVS) is a synchrotron-based technique that allows selective observation of vibrational modes of Mössbauer-active nuclei. Using the ${ }^{57} \mathrm{Fe}$ nuclear resonance at $14.4 \mathrm{keV}$, NRVS has provided valuable structural information about $[\mathrm{NiFe}]-,{ }^{12-14}[\mathrm{FeFe}]-,{ }^{15,16}$ and [Fe]-hydrogenases. ${ }^{17}$ A typical NRV spectrum of [NiFe]hydrogenase comprises dominant $\mathrm{Fe}-\mathrm{S}(-\mathrm{Fe})$ stretching and bending bands in the region between $100-420 \mathrm{~cm}^{-1}$, which are mostly related to the FeS clusters of the electron transport chain, as well as $\mathrm{Fe}-\mathrm{CO} / \mathrm{CN}$ stretching and bending modes of the $[\mathrm{NiFe}]$ active site in the 400 $-650 \mathrm{~cm}^{-1}$ spectral region. Most of the iron atoms in the enzyme are located in the FeS clusters, therefore their spectral contributions surpass signals of the single active site iron. This results often in poorly-resolved $\mathrm{Fe}-\mathrm{CO} / \mathrm{CN}$ bands, which have a relatively low intensity. Furthermore, 
certain bands related to the $\mathrm{FeS}$ clusters and the [NiFe] active site are superimposed, hindering their unambiguous assignment. ${ }^{12,14,18}$

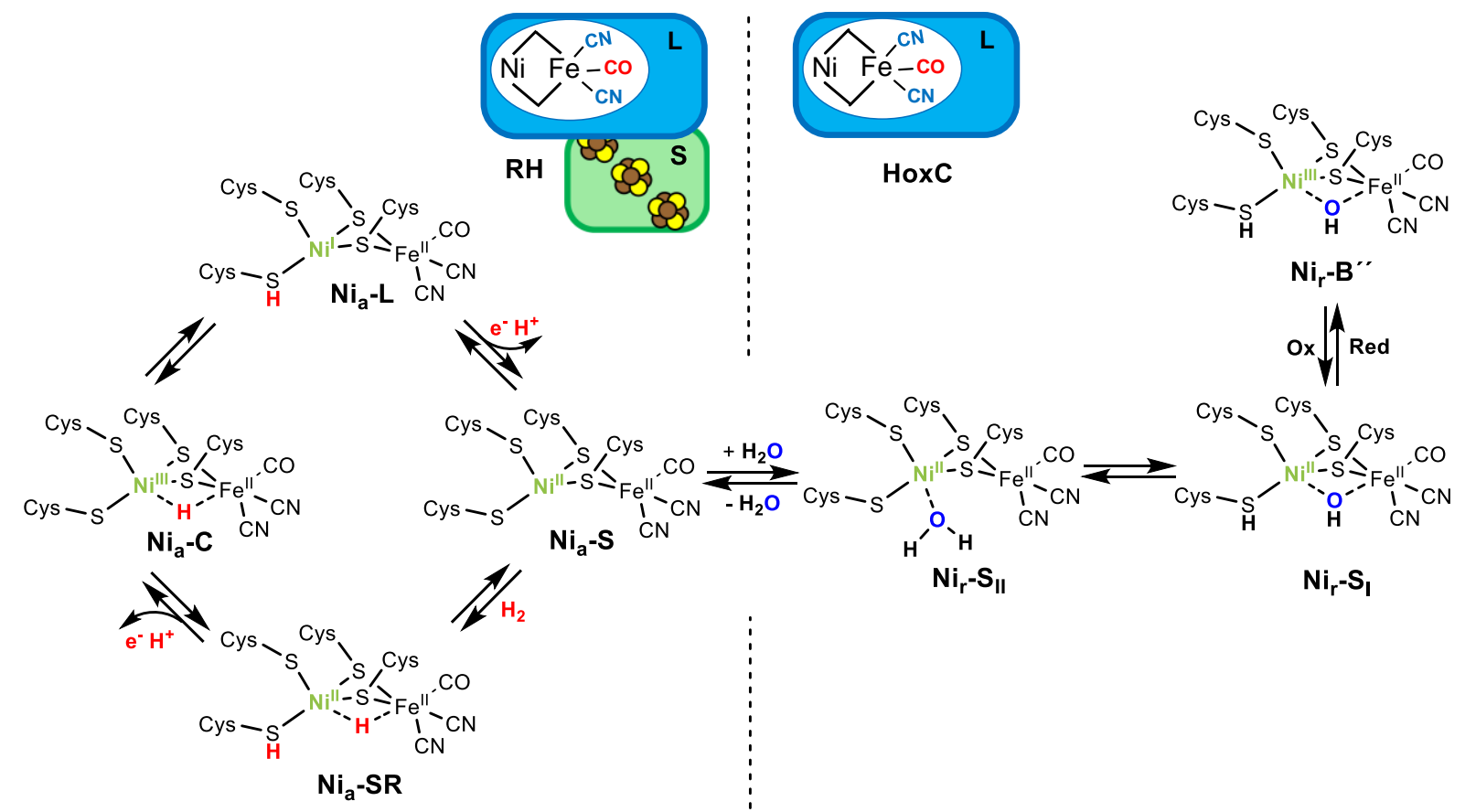

Figure 1. (Left) Schematic representation of the subunit composition of the RH and the proposed catalytic cycle of $[\mathrm{NiFe}]$-hydrogenases. The states involved in the $\mathrm{H}_{2}$ transformation include the $\mathrm{Ni}_{\mathrm{a}}-\mathrm{S}$ intermediate that presumably binds $\mathrm{H}_{2}$ in the bridging position between the nickel and the iron ions. $\mathrm{H}_{2}$ splitting results in the twoelectron reduced $\mathrm{Ni}_{\mathrm{a}}$-SR state characterized by a bridging hydride. Release of one electron and one proton results in the hydride-carrying $\mathrm{Ni}_{\mathrm{a}}-\mathrm{C}$ species, which is a tautomeric form of the $\mathrm{Ni}_{\mathrm{a}}-\mathrm{L}$ state. Release of another electron and a further proton restores the $\mathrm{Ni}_{\mathrm{a}}-\mathrm{S}$ intermediate. ${ }^{1,4}$ Protonation of a terminal cysteine as well as the bridging hydride are highlighted in red. The $\mathrm{Ni}$ and its oxidation state are depicted in green. (Right) Schematic representation of the [NiFe]-hydrogenase large subunit HoxC and proposed structures of its resting states. The asisolated HoxC protein occurs in a mixture of the $\mathrm{Ni}_{\mathrm{r}}-\mathrm{S}_{\mathrm{I}}$ and $\mathrm{Ni}_{\mathrm{r}}-\mathrm{S}_{\mathrm{II}}$ species. One-electron oxidation results in formation of the $\mathrm{Ni}_{\mathrm{r}}-\mathrm{B}$ " species. Protonation of the terminal cysteine, as found for the $\mathrm{Ni}_{\mathrm{a}}-\mathrm{SR}$ and the light-induced $\mathrm{Ni}_{\mathrm{a}}-\mathrm{L}$ intermediates (left panel), and the $\mathrm{OH}^{-} / \mathrm{H}_{2} \mathrm{O}$ active site ligands assigned in this work are depicted in bold case letters.

Recently, we isolated the catalytic subunit HoxC from the $\mathrm{O}_{2}$-tolerant regulatory [NiFe]hydrogenase (RH) of Ralstonia eutropha. ${ }^{19}$ HoxC hosts exclusively the [NiFe] active site, and it is therefore an ideal target for a detailed and exclusive spectroscopic investigation of the catalytic center without interference from the auxiliary FeS clusters. In the present study, we applied low-temperature IR and NRVS techniques together with density functional theory (DFT) calculations to gain structural information of so-far barely defined hydroxy-bridged active site states of [NiFe]-hydrogenase. We uncovered vibrational bands of the active site in a broad spectral range, thus far superimposed by the Fe-S vibrations. Therefore, we were able to define new structural determinants of the catalytic center, which may represent benchmarks for 
future NRVS studies on site-selectively labeled hydrogenases as well as biomimetic [NiFe] compounds.

\section{Results and Discussion}

\section{IR detection of $\mathrm{CO}$ and $\mathrm{CN}^{-}$ligands of the [NiFe] active site at ambient and cryogenic temperatures}

The as-isolated HoxC protein $\left(\mathrm{HoxC}_{\mathrm{ai}}\right)$ contains a stoichiometric amount of the $[\mathrm{NiFe}]$ active site, which resided in the diamagnetic and isoelectronic $\mathrm{Ni}_{\mathrm{r}}-\mathrm{S}_{\mathrm{I}}$ and $\mathrm{Ni}_{\mathrm{r}}-\mathrm{S}_{\text {II }}$ states at ambient temperature (Figs. 1 and 2a). ${ }^{1,19}$ A previous study showed that these states can be partially interconverted by shifting the $\mathrm{pH}$ of the buffer. ${ }^{19}$ This has been interpreted with the presence of a protonatable bridging ligand at the active site, attributed to a hydroxy $\left(\mathrm{OH}^{-}\right)$group (Fig. 1). ${ }^{20-}$

${ }^{22}$ Native $\mathrm{RH}$, for comparison, resided preferentially in the $\mathrm{Ni}_{\mathrm{a}}-\mathrm{S}$ state characterized by a vacant bridging position and a CO absorption in the IR spectrum at $1943 \mathrm{~cm}^{-1}$, which remains stable over a broad pH-range (Fig. S1). ${ }^{19,23}$ As NRVS is conducted at cryogenic conditions (estimated sample temperature of $40-80 \mathrm{~K}$ ), it is appropriate to record the corresponding IR spectra of the HoxC and RH proteins at similarly low temperatures to allow a direct comparison of the two spectroscopic techniques. In fact, the mixture of the $\mathrm{Ni}_{\mathrm{r}}-\mathrm{S}_{\mathrm{I}}$ and $\mathrm{Ni}_{\mathrm{r}}-\mathrm{S}_{\mathrm{II}}$ states, observed for $\mathrm{HoxC}_{\mathrm{ai}}$ at $283 \mathrm{~K}$, converted into an almost pure $\mathrm{Ni}_{\mathrm{r}}-\mathrm{S}_{\mathrm{I}}$ species at $85 \mathrm{~K}$ characterized by a CO absorption at $1955 \mathrm{~cm}^{-1}$ (Fig. 2b). According to our previous interpretation, ${ }^{19}$ the $\mathrm{Ni}_{\mathrm{r}}-\mathrm{S}_{\mathrm{I}}$ and $\mathrm{Ni}_{\mathrm{r}}-\mathrm{S}_{\text {II }}$ species just differ in the protonation state of the bridging ligand $\left(\mathrm{OH}^{-}\right.$vs. $\left.\mathrm{H}_{2} \mathrm{O}\right)$. Thus, cryogenic temperatures seem to stabilize the hydroxy ligand (Fig. 1), which is presumably related to temperature-dependent changes of the active site surrounding. The enrichment of the $\mathrm{Ni}_{\mathrm{r}}-\mathrm{S}_{\mathrm{I}}$ state turns out to be reversible. Indeed, setting the temperature of the HoxC sample to $298 \mathrm{~K}(\mathrm{RT})$ restored the original $\mathrm{Ni}_{\mathrm{r}}-\mathrm{S}_{\mathrm{I}} / \mathrm{Ni}_{\mathrm{r}}-\mathrm{S}_{\text {II }}$ ratio (Fig. S2). Native $\mathrm{RH}$, by contrast, retained a single CO absorption at $1946 \mathrm{~cm}^{-1}$ in the IR spectrum, i.e. it maintained the $\mathrm{Ni}_{\mathrm{a}}-\mathrm{S}$ state at $85 \mathrm{~K}$ (Fig. 2b). Thus, HoxC and RH exhibit different IR spectra both at room temperature and under cryogenic conditions, reflecting at least slightly divergent active site structures.

In our previous work, we showed that $\mathrm{HoxC}_{\mathrm{ai}}$ protein can be oxidized with ferricyanide, revealing a species denoted as $\mathrm{HoxC}_{\mathrm{ox} .}{ }^{19}$ According to X-ray, EPR and DFT studies, standard [NiFe]-hydrogenases form paramagnetic $\mathrm{Ni}^{\mathrm{III}}$ species such as the $\mathrm{Ni}_{\mathrm{r}}-\mathrm{B}$ state upon oxidation (Fig. 1). ${ }^{1,24-26}$ The IR spectrum of $\mathrm{HoxC}_{\mathrm{ox}}$, recorded at room temperature, displayed bands assigned to $\mathrm{Ni}_{\mathrm{r}}$-B-like species termed as $\mathrm{Ni}_{\mathrm{r}}-\mathrm{B}^{\prime}$ and $\mathrm{Ni}_{\mathrm{r}}-\mathrm{B}^{\prime \prime}$, respectively. ${ }^{19}$ Low-temperature IR measurements performed on $\mathrm{HoxC}_{\mathrm{ox}}$ revealed the $\mathrm{Ni}_{\mathrm{r}}-\mathrm{B}^{\prime \prime}$ state, characterized by a $\mathrm{CO}$ absorption at $1979 \mathrm{~cm}^{-1}$, as the predominant species at $85 \mathrm{~K}$ (Fig. 2b). Oxidation of the nickel site was confirmed by EPR measurements (Fig. S3). ${ }^{19}$ The fact that almost pure $\mathrm{Ni}_{\mathrm{r}}-\mathrm{S}_{\mathrm{I}}$ and $\mathrm{Ni}_{\mathrm{r}^{-}}$ 
B" states were observed in $\mathrm{HoxC}_{\mathrm{ai}}$ and $\mathrm{HoxC}_{\mathrm{ox}}$, respectively, facilitated the establishment of DFT models, which were subsequently used to interpret the low-temperature IR and NRV spectra.
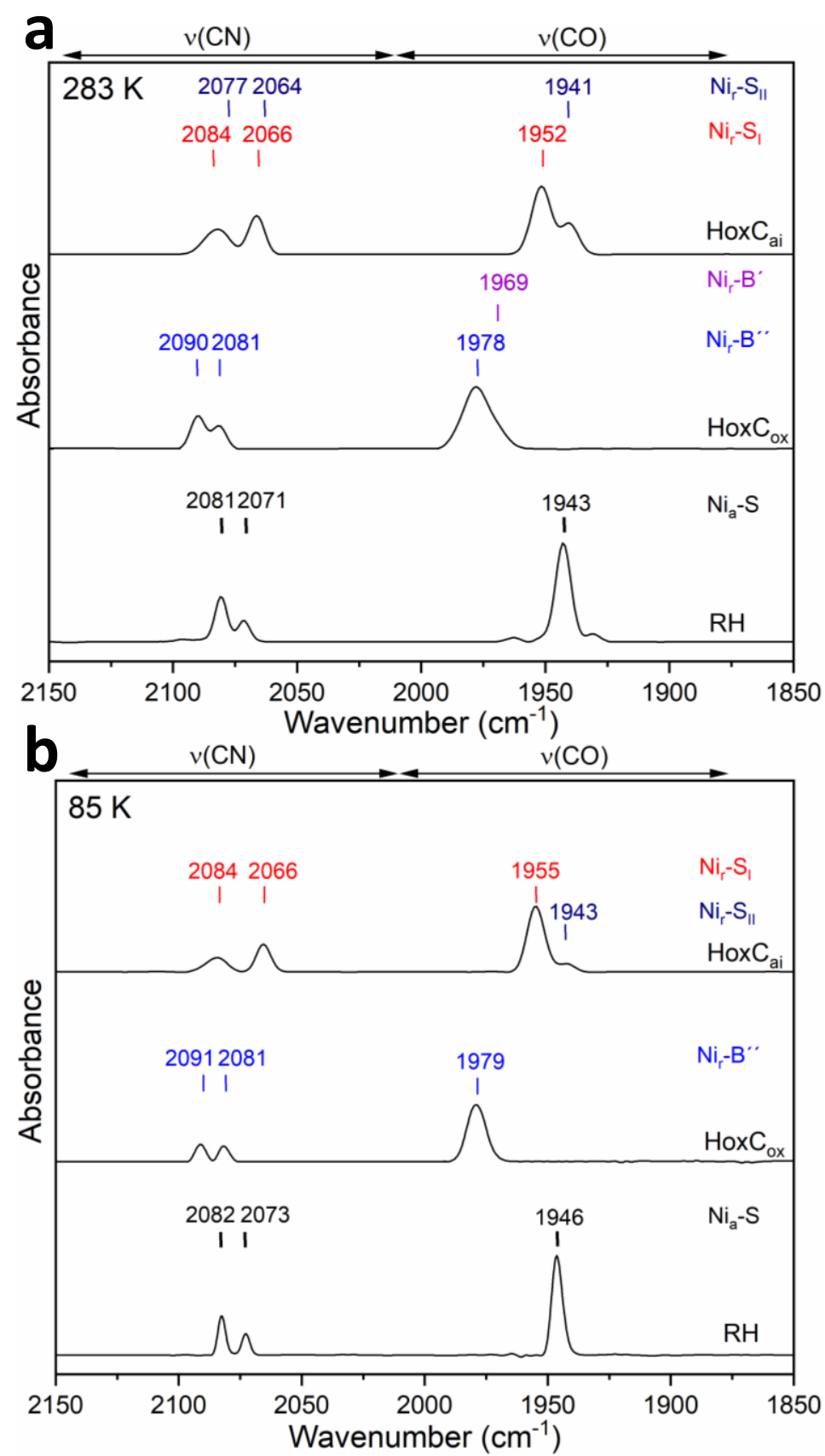

Figure 2. Infrared spectra of $\mathrm{HoxC}_{\mathrm{ai}}, \mathrm{HoxC}_{\mathrm{ox}}$ and $\mathrm{RH}$ (top to bottom) taken at $283 \mathrm{~K}$ and $85 \mathrm{~K}$. a) IR spectral region characteristic for $\mathrm{CO}$ and $\mathrm{CN}$ stretching modes recorded at $283 \mathrm{~K}$. The spectrum of $\mathrm{HoxC}_{\mathrm{ai}}$ contains spectral contributions of $\mathrm{Ni}_{\mathrm{r}}-\mathrm{S}_{\mathrm{I}}$ (red) and $\mathrm{Ni}_{\mathrm{r}}-\mathrm{S}_{\mathrm{II}}$ (dark blue) resting states, respectively. The spectrum of $\mathrm{RH}$ is dominated by signals attributed to the $\mathrm{Ni}_{\mathrm{a}}-\mathrm{S}$ state (labeled in black). The IR data of $\mathrm{HoxC}_{\mathrm{ox}}$ comprise contributions from two paramagnetic oxidized $\mathrm{Ni}_{\mathrm{r}}-\mathrm{B}^{\prime}$ (minor species) and $\mathrm{Ni}_{\mathrm{r}}-\mathrm{B}^{\prime \prime}$ states labeled in purple and blue, respectively. b) IR spectral region characteristic for $\mathrm{CO}$ and $\mathrm{CN}$ stretching modes recorded at $85 \mathrm{~K}$ for the same samples. Contributions from the corresponding $\mathrm{CN}$ absorptions of $\mathrm{Fe}(\mathrm{CN})_{6}{ }^{3-}$ and $\mathrm{Fe}(\mathrm{CN})_{6}{ }^{2-}$ present in the chemically oxidized $\mathrm{HoxC}_{\mathrm{ox}}$ were subtracted for sake of clarity. ${ }^{19}$ 


\section{DFT modeling of the HoxC active site in the $\mathrm{Ni}_{\text {r-S}} \mathrm{S}$ - and $\mathrm{Ni}$-B-like states}

DFT calculations were used to model structural details and vibrational spectra of the [NiFe] active site in the $\mathrm{HoxC}_{\mathrm{ai}} / \mathrm{HoxC}_{\mathrm{ox}}$ proteins. In the absence of experimentally resolved crystallographic structures of either HoxC or native RH, the DFT modeling was based on the corresponding X-ray structure of the membrane-bound hydrogenase ( $\mathrm{MBH})$ from the same organism. ${ }^{27}$ The model setup is described in detail in the Supporting Information. In comparison to the large subunit of $\mathrm{MBH}$, our HoxC homology model revealed a larger active site pocket with a lower number of contacts between the protein side chains and the metal ligands (Fig. S4). The DFT calculations were performed for the reduced, diamagnetic, $\mathrm{Ni}_{r}-\mathrm{S}$-like $\left[\mathrm{Ni}^{\mathrm{II}} \mathrm{Fe}^{\mathrm{II}}\right]$ species with an overall spin of zero and for the oxidized, paramagnetic, $\mathrm{Ni}_{\mathrm{r}}-\mathrm{B}-$ like $\left[\mathrm{Ni}^{\mathrm{III}} \mathrm{Fe}^{\mathrm{II}}\right]$ state with spin 1/2. According to previous structural predictions for the reversibly inhibited ready-states of $[\mathrm{NiFe}]$-hydrogenases, ${ }^{1,28,29}$ our models contained a bridging hydroxy $(\mu \mathrm{OH}$ subscript in the model notations) ligand at the active site (Figs. S5-S7). For the $\mathrm{Ni}_{\mathrm{r}}-\mathrm{S}$ species, local energy minima were also obtained with a water molecule serving as either metal-bridging $\left(\mu \mathrm{H}_{2} \mathrm{O}\right)$, Ni-terminal $\left(\mathrm{Ni}-\mathrm{H}_{2} \mathrm{O}\right),{ }^{28,29}$ or Fe-terminal $\left(\mathrm{Fe}-\mathrm{H}_{2} \mathrm{O}\right)$ ligand (Figs. S8-S10). The DFT model set was further extended by considering the Ni-bound terminal cysteine Cys479 with either a protonated thiol ( $\mathrm{SH}$ superscript in the model notations), as, e.g., in the $\mathrm{Ni}_{\mathrm{r}}-\mathrm{S}_{\mu \mathrm{OH}} \mathrm{SH}$ model shown in Fig. 3a, or a deprotonated thiolate ( $\mathrm{S}^{-}$, Figs. 3b, S6-S10). This is in line with the proposed protonation of the corresponding cysteine residue in the catalytically relevant $\mathrm{Ni}_{\mathrm{a}^{-}}$ $\mathrm{SR}$ and $\mathrm{Ni}_{\mathrm{a}}-\mathrm{L}$ states of $[\mathrm{NiFe}]$-hydrogenases. ${ }^{30-34} \mathrm{We}$ also examined the second Ni-bound terminal cysteine Cys60 as possible protonation site. The corresponding $\mathrm{Ni}_{\mathrm{r}}-\mathrm{S}_{\mu \mathrm{OH}}{ }^{\mathrm{Cys} 60-\mathrm{SH}}$ model is shown in Fig. S6.

Notably, structural optimization of the $\mathrm{Ni}_{\mathrm{r}}-\mathrm{S}_{\mu} \mathrm{OH}$ models revealed an over-elongated bond between the $\mathrm{Ni}^{\mathrm{II}}$ ion and the bridging sulfur ligand of Cys482, ${ }^{19,28,35}$ whose length depended on the protonation state of the Ni-terminal cysteines. The $\mathrm{Ni}_{r}-\mathrm{S}_{\mu \mathrm{OH}}{ }^{\mathrm{SH}}, \mathrm{Ni}_{\mathrm{r}}-\mathrm{S}_{\mu \mathrm{OH}}{ }^{\mathrm{Cys} 60-\mathrm{SH}}$ and $\mathrm{Ni}_{\mathrm{r}^{-}}$ $\mathrm{S}_{\mu \mathrm{OH}}{ }^{\mathrm{S}-}$ models yielded $\mathrm{Ni}^{\mathrm{II}} \ldots \mathrm{S}(\mathrm{Cys} 482)$ distances of $2.7,2.8$ and $3.0 \AA$, respectively, consistent with an essentially lost coordination. All other Ni/Fe-S (Cys $\neq$ Cys482) distances remained within a narrow bonding range of $\sim 2.2-2.4 \AA$ across the entire model set. No bond elongation or lost coordination between the $\mathrm{Ni}^{\mathrm{III}}$ ion and the bridging sulfur ligand of Cys482 was found for the $\mathrm{Ni}_{\mathrm{r}}-\mathrm{B}_{\mu} \mathrm{OH}$ models, as, e.g., in the $\mathrm{Ni}_{\mathrm{r}}-\mathrm{B}_{\mu \mathrm{OH}}{ }^{\mathrm{SH}}$ model (Fig. 3c), in line with available crystallographic data. ${ }^{24}$ To account for the flexibility of the Ni coordination sphere, we included explicitly in the present DFT models the two short CXXC protein sequence spacers spanning the two cysteine pairs ligating the nickel (Fig. S4). 


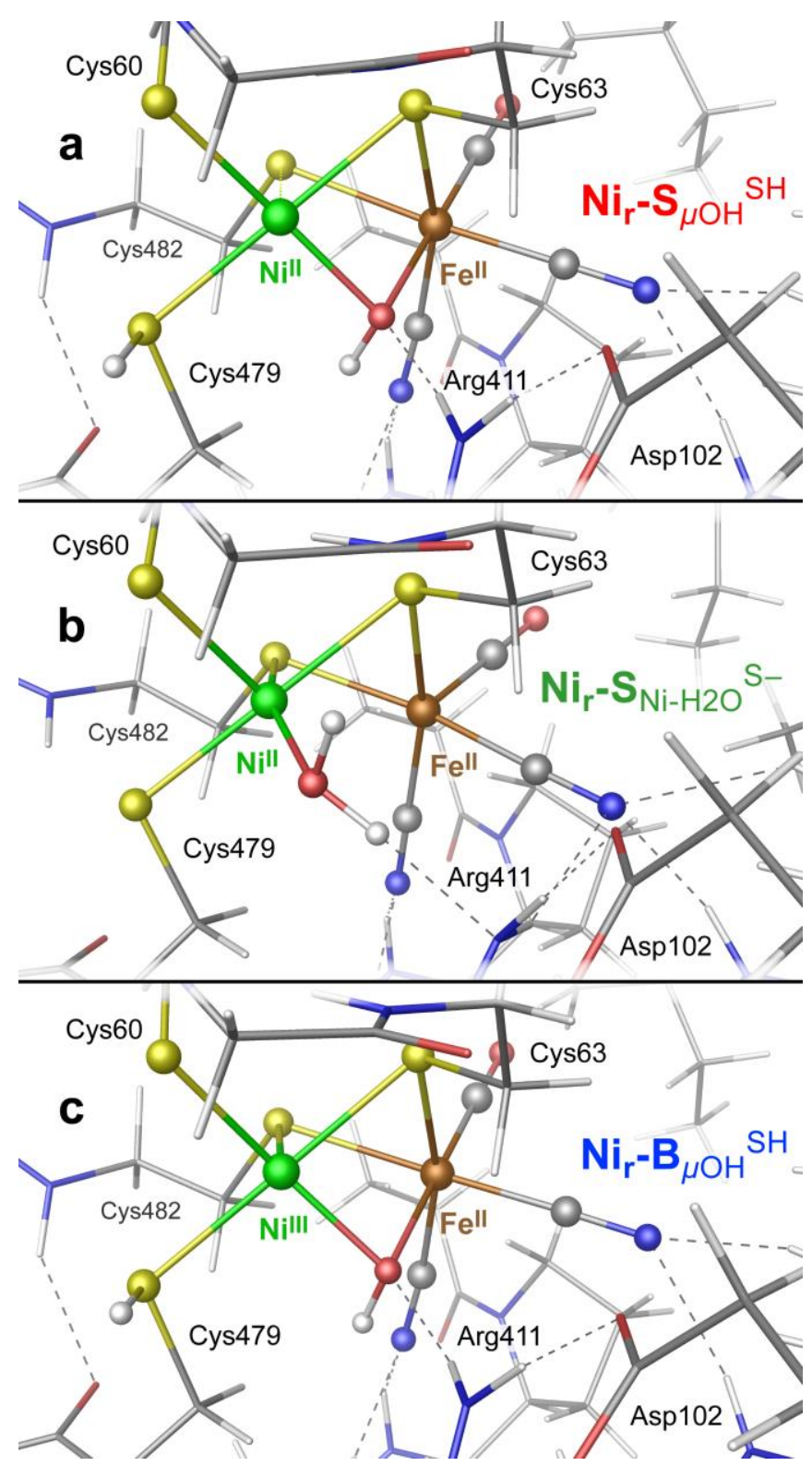

Figure 3. DFT models (a) $\mathrm{Ni}_{\mathrm{r}}-\mathrm{S}_{\mu \mathrm{OH}}{ }^{\mathrm{SH}}$ of the reduced $\mathrm{Ni}_{\mathrm{r}}-\mathrm{S}_{\mathrm{I}}$ state, (b) $\mathrm{Ni}_{\mathrm{r}}-\mathrm{S}_{\mathrm{Ni}-\mathrm{H} 2 \mathrm{O}}{ }^{\mathrm{S}-}$ of the reduced $\mathrm{Ni}_{\mathrm{r}}-\mathrm{S}_{\mathrm{II}}$ state, and (c) $\mathrm{Ni}_{\mathrm{r}}-\mathrm{B}_{\mu \mathrm{OH}}{ }^{\mathrm{SH}}$ of the oxidized $\mathrm{Ni}_{\mathrm{r}}-\mathrm{B}^{\prime \prime}$ state, displaying the [NiFe] cofactor metal ligands and their contacts to the nearby side chains in HoxC. For alternative models and the entire HoxC homology model employed, see Figs. S4S10.

\section{DFT reproduces the experimental IR spectra of the $\mathrm{Ni}_{r}-\mathrm{S}_{I}$ and $\mathrm{Ni}_{\mathrm{r}}-\mathrm{B}^{\prime \prime}$ states of $\mathrm{HoxC}$}

DFT calculations based on the $\mathrm{Ni}_{\mathrm{r}}-\mathrm{S}_{\mu \mathrm{OH}}{ }^{\mathrm{SH}}$ and $\mathrm{Ni}_{\mathrm{r}}-\mathrm{B}_{\mu \mathrm{OH}}{ }^{\mathrm{SH}}$ models (Figs. 3a and 3c, or S6 and S7) predict $\mathrm{CO}$ and $\mathrm{CN}$ stretching frequencies as well as relative IR intensities close to those detected in the low-temperature IR measurements (Fig. 2b and Figs. S11a and S11b). While the absolute positions of the DFT-simulated $\mathrm{CO}$ and $\mathrm{CN}$ bands in proteins commonly rely on a linear fit procedure (described in the Methods section of the Supporting Information), the corresponding direction of band shifts is independent of the fitting procedure and reflects a 
polarization of the Fe-bound $\mathrm{CO} / \mathrm{CN}^{-}$ligands. Thus, a charge increase of $1+$ per active site unit results in a predicted blue-shift of the CO stretching frequency of $\sim 20-30 \mathrm{~cm}^{-1}$. This is reflected by the simulated IR bands from a series of models at three levels of charge, i.e. (i) $\mathrm{Ni}_{\mathrm{r}}-\mathrm{S}_{\mu \mathrm{OH}}{ }^{\mathrm{S}-}$, (ii) $\mathrm{Ni}_{\mathrm{r}}-\mathrm{B}_{\mu \mathrm{OH}}{ }^{\mathrm{S}-} / \mathrm{Ni}_{\mathrm{r}}-\mathrm{S}_{\mu \mathrm{OH}}{ }^{\mathrm{SH}}$ and (iii) $\mathrm{Ni}_{\mathrm{r}}-\mathrm{B}_{\mu \mathrm{OH}}{ }^{\mathrm{SH}}$ (Fig. S11). The blue shift of $\sim 20-30 \mathrm{~cm}^{-1}$ is in a good agreement with the experimentally monitored spectral shift of $24 \mathrm{~cm}^{-1}$ observed for the $\mathrm{Ni}_{\mathrm{r}}-\mathrm{S}_{\mathrm{I}}\left(\mathrm{HoxC}_{\mathrm{ai}}\right)$ and $\mathrm{Ni}_{\mathrm{r}}-\mathrm{B}^{\prime \prime}\left(\mathrm{HoxC}_{\mathrm{ox}}\right)$ states (Fig. S11a and $\left.\mathrm{S} 11 \mathrm{~b}\right)$. This is consistent with the oxidation of the nickel ion from $\mathrm{Ni}^{\mathrm{II}}$ to $\mathrm{Ni}^{\mathrm{III}}$ for the $\mathrm{Ni}_{\mathrm{r}}-\mathrm{S}_{\text {I }}$ to $\mathrm{Ni}_{\mathrm{r}}-\mathrm{B}^{\prime \prime}$ conversion (Fig. S3), $22,36,37$ assuming the protonation status of Cys479 was unchanged. Altogether, the experimental and theoretical data are consistent with a total charge increase of $1+$ at the [NiFe] active site when moving from $\mathrm{HoxC}_{\mathrm{ai}}$ to $\mathrm{HoxC}_{\mathrm{ox}}$. Thus, the comparison of the experimental and DFT-computed IR spectra does not allow a conclusive statement whether or not Cys479 is protonated.

The low-temperature IR spectrum of $\mathrm{HoxC}_{\text {ai }}$ revealed also traces of the $\mathrm{Ni}_{\mathrm{r}}-\mathrm{S}_{\text {II }}$ species, identified through the $\mathrm{CO}$ band at $1943 \mathrm{~cm}^{-1}$, which is shifted just by $12 \mathrm{~cm}^{-1}$ compared to the $\mathrm{CO}$ band at $1955 \mathrm{~cm}^{-1}$ of $\mathrm{Ni}_{\mathrm{r}}-\mathrm{S}_{\mathrm{I}}$ (Fig. 2b). Therefore, the $\mathrm{Ni}_{\mathrm{r}}-\mathrm{S}_{\mathrm{I}}$ and $\mathrm{Ni}_{\mathrm{r}}-\mathrm{S}_{\mathrm{II}}$ states carry rather an identical charge. Among the different $\mathrm{Ni}_{\mathrm{r}} \mathrm{S}$ models explored, a red-shifted $\mathrm{CO}$ band with the same active site charge was computed assuming a terminal $\mathrm{H}_{2} \mathrm{O}$ ligand at the $\mathrm{Ni}$ ion and a deprotonated Cys479 $\left(\mathrm{Ni}_{\mathrm{r}}-\mathrm{S}_{\mathrm{Ni}-\mathrm{H} 2 \mathrm{O}}{ }^{\mathrm{S}-}\right.$, Figs. $3 \mathrm{~b}$ and S12, Fig. 1). The relative energy difference between the $\mathrm{Ni}_{\mathrm{r}}-\mathrm{S}_{\mathrm{Ni}-\mathrm{H} 2 \mathrm{O}}{ }^{\mathrm{S}-}$ and $\mathrm{Ni}_{\mathrm{r}}-\mathrm{S}_{\mu \mathrm{OH}}{ }^{\mathrm{SH}}$ models is just $2.0 \mathrm{kcal} / \mathrm{mol}$. Thus, the corresponding $\mathrm{Ni}_{\mathrm{r}}-\mathrm{S}_{\text {II }}$ and $\mathrm{Ni}_{\mathrm{r}}-\mathrm{S}_{\text {I }}$ species may coexist in a temperature-dependent dynamic equilibrium with a slight preference for $\mathrm{Ni}_{\mathrm{r}}-\mathrm{S}_{\mathrm{I}}$ (Fig. S2). Yet an alternative rationalization of the minor red-shifted $\mathrm{Ni}_{\mathrm{r}}-\mathrm{S}_{\mathrm{II}}$ is that it represents a species singly deprotonated with regard to the $\mathrm{Ni}_{\mathrm{r}}-\mathrm{S}_{\mathrm{I}}$ state, still

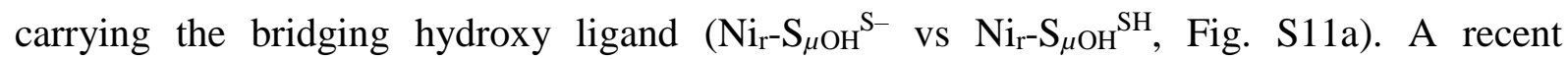
computational study supports the $\mathrm{Ni}_{\mathrm{r}}-\mathrm{S}_{\mu \mathrm{OH}}{ }^{\mathrm{SH}}$ and $\mathrm{Ni}_{\mathrm{r}}-\mathrm{S}_{\mathrm{Ni}-\mathrm{H} 2 \mathrm{O}}{ }^{\mathrm{S}-}$ active sites assignment for the $\mathrm{Ni}_{\mathrm{r}}-\mathrm{S}_{\mathrm{I} / \mathrm{II}}$ states. ${ }^{35}$

\section{Experimental and DFT-computed NRVS data of the active site in $\mathrm{HoxC}_{\mathrm{ai}}$ and $\mathrm{Hox}_{\mathrm{ox}}$ proteins}

The NRV spectra of ${ }^{57} \mathrm{Fe}$-enriched Hox $\mathrm{C}_{\mathrm{ai}}$ and $\mathrm{RH}$ are shown in Fig. 4. As native RH harbors three $[4 \mathrm{Fe} 4 \mathrm{~S}]$ clusters, bands originating from the FeS clusters dominate the corresponding spectrum. The spectral contributions of the $[\mathrm{NiFe}]$ site are relatively weak and visible only in the high-frequency region of $420-600 \mathrm{~cm}^{-1}$ (Fig. 4). ${ }^{12}$ Further details about the NRVS characterization of RH are provided in the Supporting Information (Supplementary Results and Figs. S13-14). The most intense active site bands in RH are detected at $553 \mathrm{~cm}^{-1}$ and $596 \mathrm{~cm}^{-1}$ and are attributed mainly to $\mathrm{Fe}-\mathrm{CO}$ stretching and bending vibrations. ${ }^{12}$ Bands below $530 \mathrm{~cm}^{-1}$, 
which are related to $\mathrm{Fe}-\mathrm{CN}$ and mixed $\mathrm{Fe}-\mathrm{CO} / \mathrm{CN}$ modes, could not be properly resolved due to their relatively low intensity.

NRV spectra for the $\operatorname{Hox}_{a i}$ and $\mathrm{HoxC}_{\mathrm{ox}}$ samples were obtained under conditions identical to those applied for the cryogenic IR measurements. The NRV spectrum of the HoxC $\mathrm{C}_{\mathrm{a}}$ sample, which mostly resided in the $\mathrm{Ni}_{\mathrm{r}}-\mathrm{S}_{\text {I }}$ state (Fig. 2b), comprises main bands at 554, 600 and $612 \mathrm{~cm}^{-1}$ in addition to features at 507, 474, 445 and $427 \mathrm{~cm}^{-1}$ (Fig. 4). The corresponding spectrum of the HoxC $\mathrm{C}_{\text {ox }}$ protein, which mostly resided in the $\mathrm{Ni}_{\mathrm{r}}-\mathrm{B}^{\prime \prime}$ state (Fig. 2b), is shown in Fig. S15. Due to the lack of FeS clusters, the observed bands could be attributed exclusively to the $[\mathrm{NiFe}]$ center. This also led to a notable increase of the intensity of the characteristic $\mathrm{Fe}-$ $\mathrm{CO} / \mathrm{CN}$ vibrations in the $400-600 \mathrm{~cm}^{-1}$ region compared to the $\mathrm{RH}$ spectrum (Fig. 4, red shaded rectangle). Moreover, we also observed spectral contributions of the active site in the low-frequency region with a main band at $180 \mathrm{~cm}^{-1}$. These contributions were so far hidden by signals related to the FeS clusters (Fig. 4). Consistent with the low-temperature IR spectroscopic measurements (Fig. 2b), the spectral differences of the NRVS data indicate that the catalytic centers of $\mathrm{RH}\left(\mathrm{Ni}_{\mathrm{a}}-\mathrm{S}\right)$ and $\mathrm{HoxC}_{\mathrm{ai}}\left(\mathrm{Ni}_{\mathrm{r}}-\mathrm{S}_{\mathrm{I}}\right)$ reside in different states (Fig. 1).

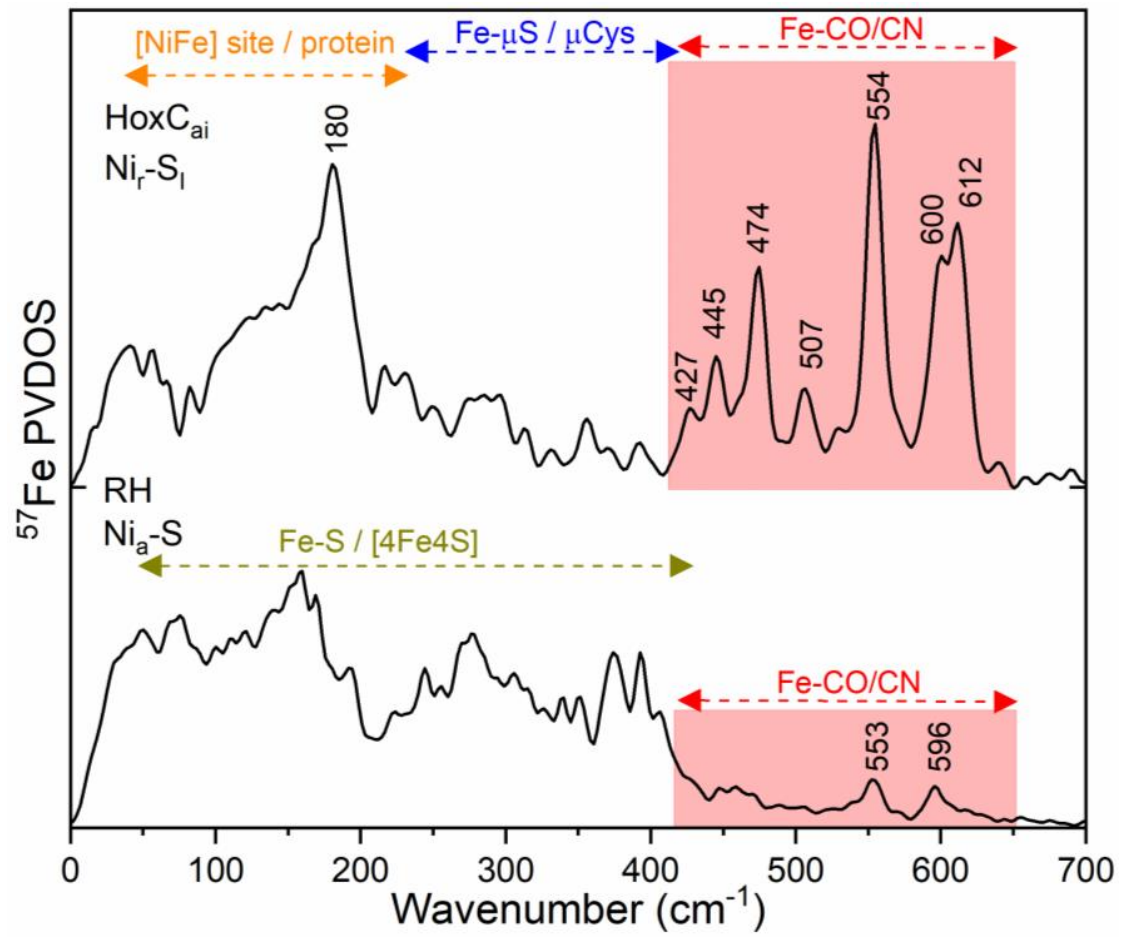

Figure 4. NRVS partial vibrational density of states (PVDOS) of ${ }^{57} \mathrm{Fe}-$ labeled RH (bottom) and its large subunit HoxC (top), in their as isolated forms, normalized to an integrated PVDOS of 3. Different spectral regions are indicated with arrows using the following color code: red, bands related to $\mathrm{Fe}-\mathrm{CO} / \mathrm{CN}$ of the $[\mathrm{NiFe}]$ active site; orange, bands related to $[\mathrm{NiFe}]$ site / protein modes; blue, bands related to $\mathrm{Fe}-\mu \mathrm{S}$ modes involving bridging cysteines; olive, bands related to Fe-S modes of the [4Fe4S]-clusters. Representative bands in the RH and HoxC spectra are labeled with numbers in black. The corresponding NRVS data including the error bars are presented in Fig. S21. 
The DFT models described above (Figs. S6-S10) were used to generate ${ }^{57} \mathrm{Fe}-\mathrm{PVDOS}$ profiles of the HoxC $\mathrm{C}_{\mathrm{ai}}$ and Hox $\mathrm{C}_{\mathrm{ox}}$ proteins in the $\mathrm{Ni}_{\mathrm{r}}-\mathrm{S}_{\mathrm{I}}$ and $\mathrm{Ni}_{\mathrm{r}}-\mathrm{B}^{\prime \prime}$ states, respectively (Figs. $\mathrm{S} 16$ and S17). Fig. 5 shows a comparison of the $\mathrm{HoxC}_{\mathrm{ai}}$ experimental spectrum $\left(0-700 \mathrm{~cm}^{-1}\right.$ region) with the DFT-calculated spectra based on the $\mathrm{Ni}_{\mathrm{r}}-\mathrm{S}$ models. The computed data based on the $\mathrm{Ni}_{\mathrm{r}}-\mathrm{S}_{\mu \mathrm{OH}}{ }^{\mathrm{S}-}$ and $\mathrm{Ni}_{\mathrm{r}}-\mathrm{S}_{\mu \mathrm{OH}}{ }^{\mathrm{SH}}$ models - both carrying a bridging hydroxy group - reproduce excellently the experimental spectrum (Fig. 5a, Figs. S16 and S18).
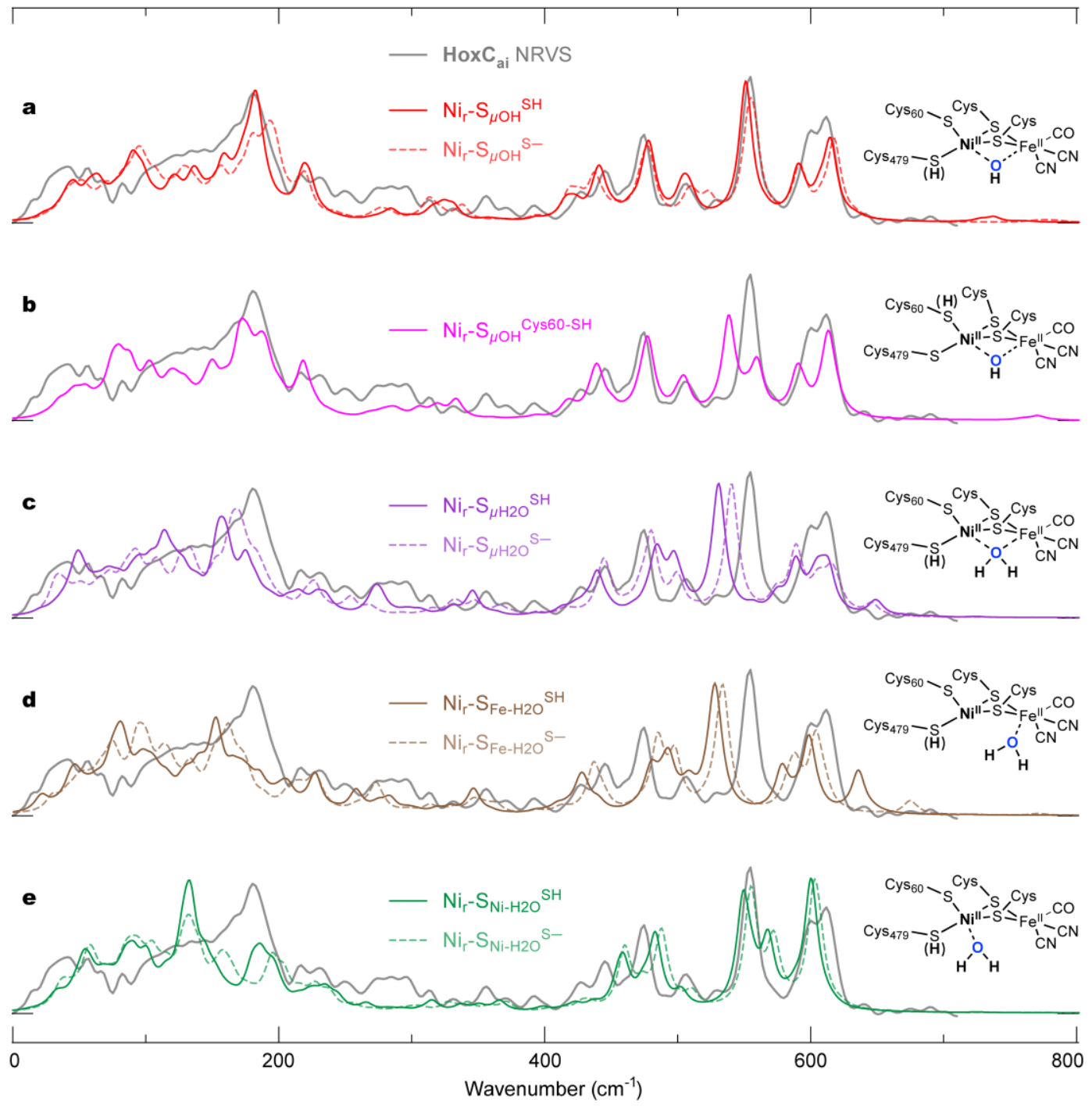

Figure 5. Comparison of the experimental NRV spectrum of the $\mathrm{HoxC}_{\mathrm{ai}}$ sample $\left(\mathrm{Ni}_{\mathrm{r}}-\mathrm{S}_{\mathrm{I}}\right.$, grey trace in a-e) overlaid with the corresponding DFT-calculated ${ }^{57} \mathrm{Fe}-\mathrm{PVDOS}$ bands using alternative $\left[\mathrm{Ni}^{\mathrm{II}} \mathrm{Fe}^{\mathrm{II}}\right]$ models, schematically shown right hand of the spectra. The DFT spectra derived using either the protonated (solid lines) or deprotonated (broken lines) Cys479 are shown for the following models: (a, red) best-fit $\mathrm{Ni}_{\mathrm{r}}-\mathrm{S}_{\mu \mathrm{OH}}{ }^{\mathrm{SH}}$ and $\mathrm{Ni}_{\mathrm{r}}-\mathrm{S}_{\mu \mathrm{OH}}{ }^{\mathrm{S}-}$ (Fig. S6);

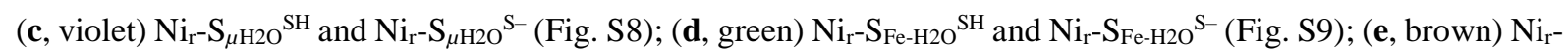
$\mathrm{S}_{\mathrm{Ni}-\mathrm{H} 2 \mathrm{O}}{ }^{\mathrm{SH}}$ and $\mathrm{Ni}_{\mathrm{r}}-\mathrm{S}_{\mathrm{Ni}-\mathrm{H} 2 \mathrm{O}^{\mathrm{S}-}}$ (Fig. S10). The DFT spectrum derived from the alternative hydroxy model with a protonated Cys60, $\mathrm{Ni}_{\mathrm{r}}-\mathrm{S}_{\mu \mathrm{OH}}{ }^{\mathrm{Cy} 60-\mathrm{SH}}$, is highlighted in $\mathbf{b}$ (magenta). Both $\mu \mathrm{OH}^{-}$models in a reproduce the experimental data in the $\mathrm{Fe}-\mathrm{CO} / \mathrm{CN}$ region above $400 \mathrm{~cm}^{-1}$. Minor differences in the low-frequency spectral region around $180 \mathrm{~cm}^{-1}$ (Fig. S16) strengthen the $\mathrm{Ni}_{\mathrm{r}}-\mathrm{S}_{\mu \mathrm{OH}}{ }^{\mathrm{SH}}$ model, in line with the better prediction of the experimental IR absorptions for the $\mathrm{CO}$ and $\mathrm{CN}$ stretching modes (Fig. S11a). 
All the other models, carrying either a bridging $\mathrm{H}_{2} \mathrm{O}\left(\mathrm{Ni}_{\mathrm{r}}-\mathrm{S}_{\mu \mathrm{H} 2 \mathrm{O}}{ }^{\mathrm{S}-}\right.$ and $\mathrm{Ni}_{\mathrm{r}}-\mathrm{S}_{\mu \mathrm{H} 2 \mathrm{O}}{ }^{\mathrm{SH}}$, Fig. 5c), a terminal, Ni-bound water molecule $\left(\mathrm{Ni}_{\mathrm{r}}-\mathrm{S}_{\mathrm{Ni}-\mathrm{H} 2 \mathrm{O}}{ }^{\mathrm{S}-}\right.$ and $\mathrm{Ni}_{\mathrm{r}}-\mathrm{S}_{\mathrm{Ni}-\mathrm{H} 2 \mathrm{O}}{ }^{\mathrm{SH}}$, Fig. 5e) or a terminal, Fe-bound water molecule $\left(\mathrm{Ni}_{\mathrm{r}}-\mathrm{S}_{\mathrm{Fe}-\mathrm{H} 2 \mathrm{O}}{ }^{\mathrm{S}-}\right.$ and $\mathrm{Ni}_{\mathrm{r}}-\mathrm{S}_{\mathrm{Fe}-\mathrm{H} 2 \mathrm{O}}{ }^{\mathrm{SH}}$, Fig. 5d) led to ${ }^{57} \mathrm{Fe}-\mathrm{PVDOS}$ signatures with an inferior match to the experimental spectrum of $\mathrm{HoxC}_{\mathrm{ai}}$. A closer examination of the low-frequency region $\left(0-200 \mathrm{~cm}^{-1}\right)$ revealed that the $\mathrm{Ni}_{\mathrm{r}}-\mathrm{S}_{\mu \mathrm{OH}}{ }^{\mathrm{SH}}$ model, which carries a protonated Cys479, provides a more accurate fit (solid line in Fig. 5a) to the experimental spectrum than the unprotonated form $\left(\mathrm{Ni}_{\mathrm{r}}-\mathrm{S}_{\mu \mathrm{OH}}{ }^{\mathrm{S}-}\right.$, dotted line in Fig. 5a, see also Fig. S16). This conclusion is in line with the results from the calculations of the corresponding IR absorption spectra (Fig. S11a). Notably, an alternative hydroxy-bridged model in which Cys60 is protonated $\left(\mathrm{Ni}_{\mathrm{r}}-\mathrm{S}_{\mu \mathrm{OH}}{ }^{\mathrm{Cys} 60-\mathrm{SH}}\right)$ revealed a distinct $\sim 20 \mathrm{~cm}^{-1}$ splitting of the high-intensity $\sim 550 \mathrm{~cm}^{-1}$ band and is therefore rather incompatible with the experimental spectrum (Fig. $5 \mathrm{~b}$ ). Explanations for this and other effects influencing the ${ }^{57} \mathrm{Fe}-\mathrm{PVDOS}$ profiles are provided in the Supplementary Results.

The experimental spectrum of $\mathrm{HoxC}_{\mathrm{ox}}$ was best reproduced by DFT-computed data based on the $\mathrm{Ni}_{\mathrm{r}}-\mathrm{B}_{\mu \mathrm{OH}}{ }^{\mathrm{SH}}$ model, which contains a protonated Cys479 cysteine (Fig. S17). Thus, the $\mathrm{Ni}_{\mathrm{r}}-\mathrm{S}_{\mathrm{I}}$ and $\mathrm{Ni}_{\mathrm{r}}-\mathrm{B}^{\prime \prime}$ states differ just by oxidation state of the $\mathrm{Ni}$ ion, and the $\mathrm{Ni}_{\mathrm{r}}-\mathrm{S}_{\mathrm{I}}$ to $\mathrm{Ni}_{\mathrm{r}}-\mathrm{B}^{\prime \prime}$ transition represents a one-electron oxidation of $\mathrm{Ni}^{\mathrm{II}}$ to $\mathrm{Ni}^{\mathrm{III}} \cdot{ }^{20,22,36}$ This is fully consistent with our DFT-supported IR analysis (Figs. 2b and Fig. S11) and the EPR measurements (Fig. S3). Accordingly, the NRVS data of the HoxC $\mathrm{Cx}_{\mathrm{ox}}$ sample (Fig. 6, blue trace) revealed red-shifts of 8$15 \mathrm{~cm}^{-1}$ of bands in the region above $500 \mathrm{~cm}^{-1}$ dominated by the $\mathrm{Fe}-\mathrm{CO}$ stretching vibrations (Fig. 6) compared to the $\mathrm{HoxC}_{\mathrm{ai}}$ sample (Fig. 6, red trace), thereby reflecting oxidation of the active site. Red-shifts of this magnitude are predicted by the corresponding DFT models with a protonated Cys479 $\left(\mathrm{Ni}_{\mathrm{r}}-\mathrm{S}_{\mu \mathrm{OH}}{ }^{\mathrm{SH}}\right.$, dotted red trace $\rightarrow \mathrm{Ni}_{\mathrm{r}}-\mathrm{B}_{\mu \mathrm{OH}}{ }^{\mathrm{SH}}$, dotted blue trace). The related models without terminal cysteine protonation $\left(\mathrm{Ni}_{\mathrm{r}}-\mathrm{S}_{\mu} \mathrm{OH}^{\mathrm{S}^{-}} \rightarrow \mathrm{Ni}_{\mathrm{r}}-\mathrm{B}_{\mu} \mathrm{OH}^{\mathrm{S}^{-}}\right)$revealed smaller band shifts, which do not fit the experimental data (Fig. 6). 


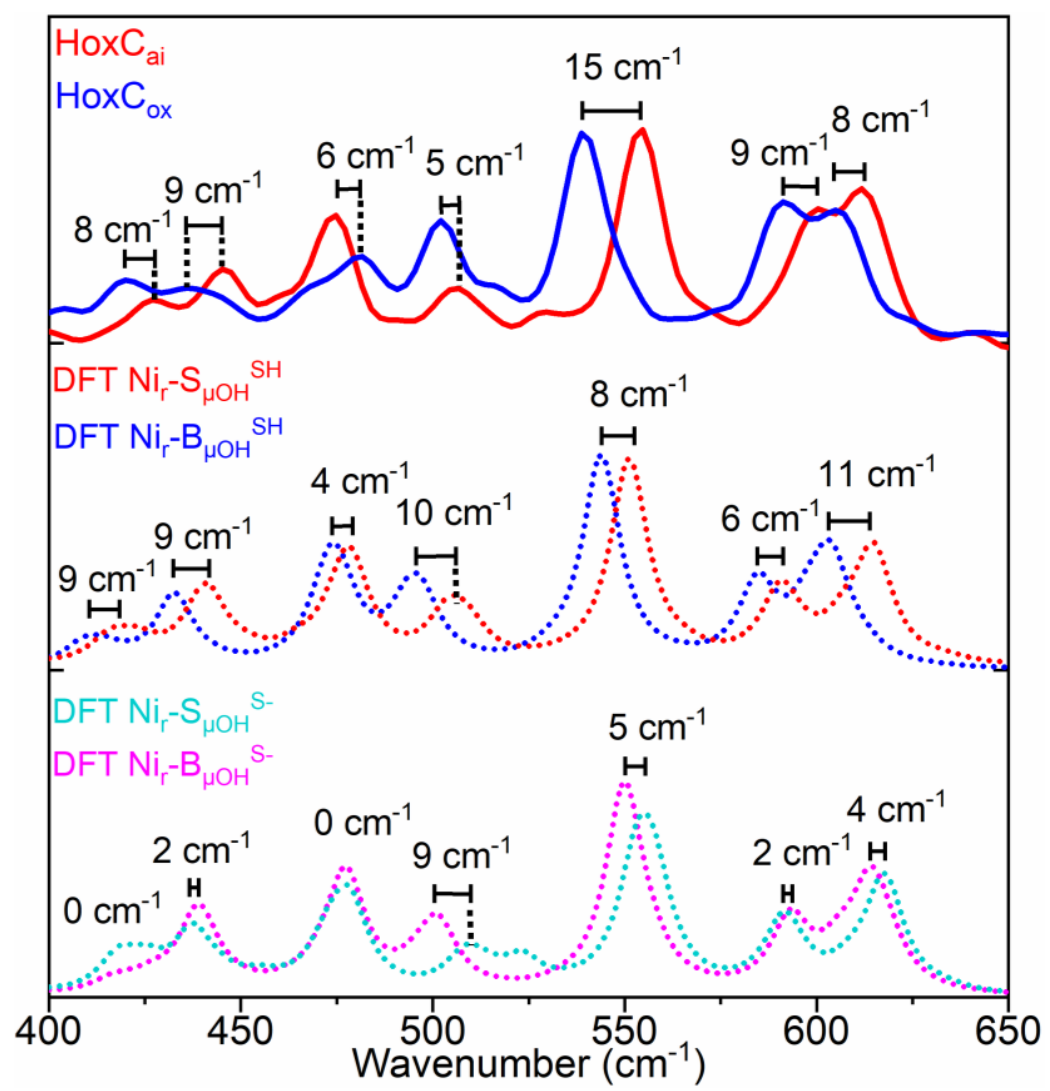

Figure 6. Comparison of the experimentally observed and DFT-calculated ${ }^{57} \mathrm{Fe}-\mathrm{PVDOS}$ bands in the $400-650 \mathrm{~cm}^{-}$ ${ }^{1}$ spectral region for $\mathrm{HoxC}_{\mathrm{ai}}$ and $\mathrm{HoxC}_{\mathrm{ox}}$. Experimental spectra (top: red trace, Hox $\mathrm{C}_{\mathrm{ai}}$; blue trace, HoxC $\mathrm{C}_{\mathrm{ox}}$ ) are compared to their DFT-calculated counterparts based on the corresponding models that contain either a protonated (middle: $\mathrm{Ni}_{\mathrm{r}}-\mathrm{S}_{\mu \mathrm{OH}}{ }^{\mathrm{SH}}$ and $\mathrm{Ni}_{\mathrm{r}}-\mathrm{B}_{\mu \mathrm{OH}}{ }^{\mathrm{SH}}$ states) or deprotonated Ni-bound terminal cysteine (bottom: $\mathrm{Ni}_{\mathrm{r}}-\mathrm{S}_{\mu \mathrm{OH}}{ }^{\mathrm{S}-}$ and $\mathrm{Ni}_{\mathrm{r}}-\mathrm{B}_{\mu \mathrm{OH}}{ }^{\mathrm{S}-}$ states). Bands calculated using $\mathrm{Ni}_{\mathrm{r}}-\mathrm{S}_{\mu \mathrm{OH}}{ }^{\mathrm{SH}}$ and $\mathrm{Ni}_{\mathrm{r}}-\mathrm{B}_{\mu \mathrm{OH}}{ }^{\mathrm{SH}}$ models are in better agreement with the NRVS data, including their shift magnitudes marked in the figure. The corresponding NRVS data including the error bars are presented in Fig. S21.

Notably, while oxidation of the active site led to a red-shift of the $\mathrm{Fe}-\mathrm{CO} / \mathrm{CN}$ vibrations in NRVS (Fig. 6), a blue-shift was observed for the IR stretching frequencies of the active site $\mathrm{CO} / \mathrm{CN}^{-}$ligands (Fig. $2 \mathrm{~b}$ ). This can be rationalized by charge polarization effects at the Fe site. Stronger bonds within the diatomic ligands, reflected by the blue-shifted IR CO and CN stretching bands, imply, in turn, weaker $\mathrm{Fe}-\mathrm{CO} / \mathrm{CN}$ bonds, resulting in a red-shift of the corresponding NRVS bands.

Taking advantage of the good concordance between the experimental and computed vibrational spectra, we were able to unveil the most prominent bridging hydroxy $\mu \mathrm{OH}^{-}$ displacements in the active site of HoxC (Fig. S19b-d). These are the Ni- $\mu \mathrm{OH}$ stretching ( $\left.490-510 \mathrm{~cm}^{-1}\right), \mathrm{Fe}-\mu \mathrm{OH}$ stretching $\left(\sim 410-430 \mathrm{~cm}^{-1}\right)$, and $\mathrm{Ni}-\mu \mathrm{OH}-\mathrm{Fe}$ wagging $(\sim 270-$ $280 \mathrm{~cm}^{-1}$ ) modes (Supplementary Results and Fig. S20). In spite of their inherently low ${ }^{57} \mathrm{Fe}-$ PVDOS intensities, the $\mathrm{Ni}-\mu \mathrm{OH}$ and $\mathrm{Fe}-\mu \mathrm{OH}$ stretches gain their spectral visibility through a 
vibrational coupling to the $\mathrm{Fe}-\mathrm{CO} / \mathrm{CN}$ modes of higher intensities. They are associated with the experimental NRVS features at $507 / 502(\mathrm{Ni}-\mu \mathrm{OH})$ and $427 / 420 \mathrm{~cm}^{-1}(\mathrm{Fe}-\mu \mathrm{OH})$ of $\mathrm{Ni}_{\mathrm{r}}-\mathrm{S}_{\mathrm{I}}$ and $\mathrm{Ni}_{\mathrm{r}}-\mathrm{B}^{\prime \prime}$, respectively (Figs. S16a/S17a). Because of their relatively low intensity, no specific bands in the experimental NRV spectra could be confidently associated with the essentially pure $\mathrm{Ni}-\mu \mathrm{OH}-\mathrm{Fe}$ wagging modes. A normal mode animation of the $[\mathrm{NiFe}]$ active site displacements for the best-fit $\mathrm{Ni}_{\mathrm{r}}-\mathrm{S}_{\mu \mathrm{OH}}{ }^{\mathrm{SH}}$ and $\mathrm{Ni}_{\mathrm{r}}-\mathrm{B}_{\mu} \mathrm{OH}{ }^{\mathrm{SH}}$ models is available as part of the Supporting Information.

\section{Conclusions}

With the present study, we provide insight into the active site structure of two interconvertible redox states of the $[\mathrm{NiFe}]$-hydrogenase active site by means of vibrational spectroscopy accompanied by DFT calculations. Specific ${ }^{57} \mathrm{Fe}$ enrichment of the catalytic subunit, HoxC, of the regulatory [NiFe]-hydrogenase from $R$. eutropha resulted in a strong enhancement of the active site spectral features, as revealed by the NRVS analysis. The absence of FeS clusters enabled the observation of low-intensity $\mathrm{Fe}-\mathrm{CO} / \mathrm{CN}$ vibrations as well as active site bands generally covered by the strong spectral contribution of FeS cluster signals. By combining NRVS with cryo-IR spectroscopy, we targeted the two hydroxy-bridged $\mathrm{Ni}_{\mathrm{r}}-\mathrm{S}_{\mathrm{I}}$ and $\mathrm{Ni}_{\mathrm{r}}-\mathrm{B}$ " states of the $[\mathrm{NiFe}]$ active site, which turned out to differ just in the oxidation state of the $\mathrm{Ni}$ ion. In fact, the two DFT-based homology models of the catalytic center $\mathrm{Ni}_{\mathrm{r}}-\mathrm{S}_{\mu} \mathrm{OH}{ }^{\mathrm{SH}}$ and $\mathrm{Ni}_{\mathrm{r}}-\mathrm{B}_{\mu \mathrm{OH}}{ }^{\mathrm{SH}}$, comprising a bridging $\mathrm{OH}^{-}$ligand and a protonated terminal cysteine, reproduced accurately the active site bands obtained by NRV and cryo-IR spectroscopy.

Previous studies suggested a protonatable bridging hydroxy ligand between $\mathrm{Ni}$ and $\mathrm{Fe}$ ions in the $\mathrm{Ni}_{\mathrm{r}}-\mathrm{S}$ state(s), ${ }^{21,22,38,39}$ whose removal produces the catalytically competent $\mathrm{Ni}_{\mathrm{a}}-\mathrm{S}$ intermediate. ${ }^{30,40}$ Our results provide structural details for these states, including a protonated terminal cysteine, which is consistent with previous studies supporting a conserved protonation state in the $\mathrm{Ni}_{\mathrm{r}}-\mathrm{B}$ and $\mathrm{Ni}_{\mathrm{r}}-\mathrm{S}_{\text {I }}$ resting states. ${ }^{22,36,37,41}$

Another important outcome of the present work is that temperature has a huge impact on the equilibrium distribution of the enzymes' redox states. Therefore, samples measured at ambient temperature by, e.g., infrared spectroscopy, should be used with care as a reference for experiments performed at cryogenic temperatures. This conclusion proved to be valid also for [FeFe]-hydrogenases. ${ }^{42,43}$ It can probably be extended to the structural characterization of other biological and synthetic catalysts where spectroscopic measurements at room temperature, e.g. IR, UV-visible, are used to interpret data collected using cryogenic techniques, including EPR and the synchrotron-related X-ray crystallography, NRVS and XAS. 
In summary, our study demonstrated the power of advanced vibrational spectroscopic techniques at cryogenic temperatures in combination with DFT calculations to elucidate the molecular active site structure of metalloenzymes. Here, we enriched and studied two hydroxycontaining redox states of $[\mathrm{NiFe}]$-hydrogenases. In case catalytic intermediates can be trapped in a homogeneous manner, this strategy will be useful to unravel their corresponding active site architectures.

Electronic supplementary information (ESI) available: Materials and Methods, Supplementary Results including Figures S1-S21 (PDF). Selected normal mode animations (GIF format) of relevant NRVS bands (ZIP archive). Optimized structures (XYZ format) for all DFT-computed models (ZIP archive). See DOI:

\section{Conflicts of interest}

There are no conflicts to declare.

\section{Acknowledgements}

G.C., O.L., I.Z., P.H. and S.P.C. are grateful to the Einstein Foundation Berlin for funding (grant number EVF-2016-277). This work was also funded by the Deutsche Forschungsgemeinschaft (DFG, German Research Foundation) under Germany's Excellence Strategy - EXC 2008 - 390540038 - UniSysCat. The authors are indebted for EU financial support (Article 38.1.2, GA) within the European Union's Horizon 2020 research and innovation program under grant agreement No 810856. S.P.C. acknowledges funding for his work through NIH GM-65440. NRVS data collection was supported by the [2017B1321], [2016B1316] and [2017B1115] Spring-8 proposals.

\section{References:}

1 W. Lubitz, H. Ogata, O. Rüdiger, E. Reijerse, Chem. Rev., 2014, 114, 4081-4148.

2 H. S. Shafaat, O. Rüdiger, H. Ogata, W. Lubitz, Biochim. Biophys. Acta BBA - Bioenerg., 2013, 1827, 986-1002.

3 D. Tombolelli, M. A. Mroginski, J. Phys. Chem. B, 2019, 123, 3409-3420.

4 P. A. Ash, R. Hidalgo, K. A. Vincent, ACS Catal., 2017, 7, 2471-2485.

5 R. M. Evans, E. J. Brooke, S. A. M. Wehlin, E. Nomerotskaia, F. Sargent, S. B. Carr, S. E. V. Phillips, F. A. Armstrong, Nat. Chem. Biol., 2016, 12, 46-50.

6 W. Lubitz, E. Reijerse, M. van Gastel, Chem. Rev., 2007, 107, 4331-4365.

7 M.-E. Pandelia, H. Ogata, W. Lubitz, ChemPhysChem, 2010, 11, 1127-1140.

8 R. P. Happe, W. Roseboom, A. J. Pierik, S. P. J. Albracht, K. A. Bagley, Nature, 1997, 385, $126-126$. 
9 J. E. Huyett, M. Carepo, A. Pamplona, R. Franco, I. Moura, J. J. G. Moura, B. M. Hoffman, J. Am. Chem. Soc., 1997, 119, 9291-9292.

10 M. Horch, J. Schoknecht, M. A. Mroginski, O. Lenz, P. Hildebrandt, I. Zebger, J. Am.

Chem. Soc., 2014, 136, 9870-9873.

11 E. Siebert, M. Horch, Y. Rippers, J. Fritsch, S. Frielingsdorf, O. Lenz, F. Velazquez

Escobar, F. Siebert, L. Paasche, U. Kuhlmann, F. Lendzian, M.-A. Mroginski, I. Zebger, P.

Hildebrandt, Angew. Chem. Int. Ed., 2013, 52, 5162-5165.

12 S. Kamali, H. Wang, D. Mitra, H. Ogata, W. Lubitz, B. C. Manor, T. B. Rauchfuss, D.

Byrne, V. Bonnefoy, F. E. Jenney, M. W. W. Adams, Y. Yoda, E. Alp, J. Zhao, S. P.

Cramer, Angew. Chem. Int. Ed., 2013, 52, 724-728.

13 H. Ogata, T. Krämer, H. Wang, D. Schilter, V. Pelmenschikov, M. van Gastel, F. Neese, T.

B. Rauchfuss, L. B. Gee, A. D. Scott, Y. Yoda, Y. Tanaka, W. Lubitz, S. P. Cramer, Nat. Commun., 2015, 6 (1).

14 L. Lauterbach, H. Wang, M. Horch, L. B. Gee, Y. Yoda, Y. Tanaka, I. Zebger, O. Lenz, S.

P. Cramer, Chem. Sci., 2015, 6, 1055-1060.

15 R. Gilbert-Wilson, J. F. Siebel, A. Adamska-Venkatesh, C. C. Pham, E. Reijerse, H.

Wang, S. P. Cramer, W. Lubitz, T. B. Rauchfuss, J. Am. Chem. Soc., 2015, 137, 8998-9005.

16 E. J. Reijerse, C. C. Pham, V. Pelmenschikov, R. Gilbert-Wilson, A. Adamska-Venkatesh,

J. F. Siebel, L. B. Gee, Y. Yoda, K. Tamasaku, W. Lubitz, T. B. Rauchfuss, S. P. Cramer, J. Am. Chem. Soc., 2017, 139, 4306-4309.

17 Y. Guo, H. Wang, Y. Xiao, S. Vogt, R. K. Thauer, S. Shima, P. I. Volkers, T. B.

Rauchfuss, V. Pelmenschikov, D. A. Case, E. E. Alp, W. Sturhahn, Y. Yoda, S. P. Cramer, Inorg. Chem., 2008, 47, 3969-3977.

18 J. Preissler, S. Wahlefeld, C. Lorent, C. Teutloff, M. Horch, L. Lauterbach, S. P. Cramer, I. Zebger, O. Lenz, Biochim. Biophys. Acta BBA - Bioenerg., 2018, 1859, 8-18.

19 G. Caserta, C. Lorent, A. Ciaccafava, M. Keck, R. Breglia, C. Greco, C. Limberg, P.

Hildebrandt, S. P. Cramer, I. Zebger, O. Lenz, Chem. Sci., 2020, 11, 5453-5465.

20 H. Tai, Y. Higuchi, S. Hirota, Dalton Trans., 2018, 47, 4408-4423.

21 S. Kurkin, S. J. George, R. N. F. Thorneley, S. P. J. Albracht, Biochemistry, 2004, 43, 6820-6831.

22 B. Bleijlevens, F. A. van Broekhuizen, A. L. De Lacey, W. Roseboom, V. M. Fernandez,

S. P. J. Albracht, J. Biol. Inorg. Chem., 2004, 9, 743-752.

23 F. Roncaroli, E. Bill, B. Friedrich, O. Lenz, W. Lubitz, M.-E. Pandelia, Chem. Sci., 2015, 6, 4495-4507.

24 S. Frielingsdorf, J. Fritsch, A. Schmidt, M. Hammer, J. Löwenstein, E. Siebert, V.

Pelmenschikov, T. Jaenicke, J. Kalms, Y. Rippers, F. Lendzian, I. Zebger, C. Teutloff, M.

Kaupp, R. Bittl, P. Hildebrandt, B. Friedrich, O. Lenz, P. Scheerer, Nat. Chem. Biol., 2014, 10, 378-385.

25 M. van Gastel, M. Stein, M. Brecht, O. Schröder, F. Lendzian, R. Bittl, H. Ogata, Y.

Higuchi, W. Lubitz, J. Biol. Inorg. Chem., 2006, 11, 41-51.

26 Ch. Geßner, O. Trofanchuk, K. Kawagoe, Y. Higuchi, N. Yasuoka, W. Lubitz, Chem.

Phys. Lett., 1996, 256, 518-524.

27 J. Fritsch, P. Scheerer, S. Frielingsdorf, S. Kroschinsky, B. Friedrich, O. Lenz, C. M. T. Spahn, Nature, 2011, 479, 249-252.

28 T. Krämer, M. Kampa, W. Lubitz, M. van Gastel, F. Neese, ChemBioChem, 2013, 14, 1898-1905.

29 P. E. M. Siegbahn, J. W. Tye, M. B. Hall, Chem. Rev., 2007, 107, 4414-4435.

30 H. Tai, K. Nishikawa, Y. Higuchi, Z. Mao, S. Hirota, Angew. Chem. Int. Ed., 2019, 58, 13285-13290.

31 H. Ogata, K. Nishikawa, W. Lubitz, Nature, 2015, 520, 571-574.

32 A. M. Escorcia, M. Stein, Front. Chem., 2018, 6, DOI 10.3389/fchem.2018.00164. 
33 G. Dong, U. Ryde, J. Biol. Inorg. Chem., 2016, 21, 383-394.

34 P. E. M. Siegbahn, R.-Z. Liao, ACS Catal., 2020, 10, 5603-5613.

35 R. Breglia, C. Greco, P. Fantucci, L. De Gioia, M. Bruschi, Inorg. Chem., 2019, 58, 279 293.

36 A. L. De Lacey, A. Pardo, V. M. Fernández, S. Dementin, G. Adryanczyk-Perrier, E. C. Hatchikian, M. Rousset, JBIC J. Biol. Inorg. Chem., 2004, 9, 636-642.

37 C. Fichtner, C. Laurich, E. Bothe, W. Lubitz, Biochemistry, 2006, 45, 9706-9716.

38 H. Tai, L. Xu, S. Inoue, K. Nishikawa, Y. Higuchi, S. Hirota, Phys. Chem. Chem. Phys., 2016, 18, 22025-22030.

39 H. Tai, L. Xu, K. Nishikawa, Y. Higuchi, S. Hirota, Chem. Commun., 2017, 53, 1044410447.

40 Y. Ilina, C. Lorent, S. Katz, J. Jeoung, S. Shima, M. Horch, I. Zebger, H. Dobbek, Angew. Chem. Int. Ed., 2019, 58, 18710-18714.

41 C. Stadler, A. L. de Lacey, Y. Montet, A. Volbeda, J. C. Fontecilla-Camps, J. C. Conesa, V. M. Fernández, Inorg. Chem., 2002, 41, 4424-4434.

42 J. A. Birrell, V. Pelmenschikov, N. Mishra, H. Wang, Y. Yoda, K. Tamasaku, T. B.

Rauchfuss, S. P. Cramer, W. Lubitz, S. DeBeer, J. Am. Chem. Soc., 2020, 142, 222-232.

43 C. Lorent, S. Katz, J. Duan, C. J. Kulka, G. Caserta, C. Teutloff, S. Yadav, U.-P. Apfel, M.

Winkler, T. Happe, M. Horch, I. Zebger, J. Am. Chem. Soc., 2020, 142, 5493-5497. 